\title{
ANALISIS PEMILIHAN PERANGKAT LUNAK SISTEM ENTERPRISE RESOURCE PLANNING (ERP) MENGGUNAKAN ANALYTICAL HIERARCHY PROCESS (AHP): STUDI KASUS PADA PT CILIANDRA PERKASA
}

\author{
Roni Kurniawan \\ Computer Science Department, School of Computer Science Binus University \\ Jl. K.H. Syahdan No. 9, Palmerah, Jakarta Barat 11480 \\ ronikurniawan.binus@yahoo.com
}

\begin{abstract}
Enterprise Resource Planning (ERP) can be described as a concept for planning and managing organization resources to create value added for stakeholders. PT Ciliandra Perkasa as an agribusiness company realized the importance of ERP system to support their operational activities. Indeed, there are many problems on the ERP implementation. Therefore, it is needed to build a proper ERP system process to be implemented. This issue will be the research problem. Implementing a qualitative method, this research uses primary data and secondary data as samples. Tests and analysis use Analytical Hierarchical Process (AHP) which its results are expected to guide the management of PT Ciliandra Perkasa in selecting proper software of ERP application.
\end{abstract}

Keywords: ERP, planning, management, organization resources, AHP

\begin{abstract}
ABSTRAK
Enterprise Resource Planning (ERP) dapat dideskripsikan sebagai sebuah konsep perencanaan dan pengelolan sumber daya organisasi untuk menghasilkan nilai tambah bagi pihak yang berkepentingan (stakeholder) pada suatu organisasi. PT Ciliandra Perkasa sebagai perusahaan agrobisnis kelapa sawit menyadari pentingnya dukungan sistem ERP guna mendukung operasional sehari-hari. Tidak sedikit masalah yang timbul selama proses implementasi ERP. Oleh karena itu penting membuat proses pemilihan sistem ERP secara tepat dan benar untuk diimplementasikan. Permasalahan pemilihan perangkat lunak sistem ERP untuk perusahaan ini merupakan obyek penelitian dengan menerapkan metode kuantitatif yang menggunakan data primer dan data sekunder sebagai sampel. Hasil uji dan analisis yang menggunakan metode AHP (Analytical Hierarchical Process) diharapkan memberikan suatu panduan bagi manajemen PT Ciliandra Perkasa dalam memilih perangkat lunak sistem ERP yang tepat.
\end{abstract}

Kata kunci: ERP, perencanaan, pengelolaan, sumber daya organisasi, AHP 


\section{PENDAHULUAN}

PT Ciliandra Perkasa sebagai perusahaan yang bergerak di agrobisnis kelapa sawit menyadari sepenuhnya akan pentingnya peranan teknologi informasi bagi dunia bisnis. Untuk itulah perusahaan ini memerlukan dukungan sistem ERP guna mendukung operasional perusahaan sehari-hari. Selain itu, adanya dukungan dari sistem ERP akan mampu mendorong perusahaan ini untuk bersaing secara kompetitif di bidang agrobisnis kelapa sawit di Indonesia serta mampu memiliki competitive advantage yang tidak dimiliki oleh para pesaingnya.

Tak jarang timbul masalah selama proses implementasi ERP. Oleh karena itu, dibutuhkan proses pemilihan sistem ERP secara tepat dan benar untuk diimplementasikan. Beberapa pertanyaan yang menjadi rumusan masalah dalam penelitian ini antara lain: (1) Kriteria dan sub kriteria apa saja yang diperlukan untuk menentukan alternatif dalam proses pemilihan perangkat lunak sistem ERP dan bagaimana prioritasnya?; (2) Alternatif apa yang dipilih menjadi prioritas utama pada pemilihan perangkat lunak sistem ERP?

Penelitian ini ditujukan untuk memberikan rekomendasi pengambilan keputusan yang telah dibobotkan berdasarkan tingkat kepentingan (urgency) perhatian perusahaan sebelum dan pada saat melakukan pemilihan perangkat lunak ERP. Melalui penelitian ini diharapkan kualitas perangkat lunak ERP sebagai pendukung dan penggerak proses bisnis dapat memberikan keunggulan kompetitif bagi perusahaan. Selain itu melalui tesis ini juga diperoleh gambaran bahwa kekeliruan dalam pemilihan perangkat lunak ERP akan mengakibatkan munculnya berbagai permasalahan dalam proses implementasi dan juga pemenuhan kebutuhan sistem informasi dari para pengguna dalam perusahaan.

Manfaat dari hasil penelitian ini adalah dapat menjadi rekomendasi bahan pemikiran dan pertimbangan bagi manajemen PT Ciliandra Perkasa. Selain itu hasil penelitian ini merupakan bentuk sumbangan untuk memperluas wawasan dalam penggunaan AHP dalam membantu memecahkan persoalan khususnya dalam pemilihan suatu perangkat lunak.

\section{Landasan Teori}

\section{Konsep Dasar Sistem Informasi}

Informasi merupakan hal yang sangat penting bagi manajemen di dalam proses pengambilan keputusan. Informasi dapat diperoleh dari sistem informasi (information system) atau disebut juga dengan processing systems atau information processing system atau information-generating systems. sistem informasi didefinisikan oleh Robert A. Leitch dan K. Roscoe Davis dalam (Jogiyanto, 2005, 11) sebagai suatu sistem di dalam suatu organisasi yang mempertemukan kebutuhan pengolahan transaksi harian, mendukung operasi, bersifat manajerial dan kegiatan strategi dari suatu organisasi dan menyediakan pihak luar tertentu dengan laporan-laporan yang diperlukan.

\section{Sistem Enterprise Resource Planning (ERP)}

Salah satu bentuk sistem informasi yang terintegrasi adalah sistem ERP. Definsi sistem ERP (Enterprise Resource Planning) dalam (Turban, 2006, 311) adalah software yang mengintegrasikan proses perencanaan, manajemen dan penggunaan semua sumber daya dalam suatu perusahaan. sistem ERP yang dikemas dalam suatu aplikasi perangkat lunak (software) yang dapat diterapkan pada suatu organisasi atau perusahaan dan disiapkan untuk meningkatkan dan mengintegrasikan proses-proses dalam internal perusahaan, seperti sistem sumber daya manusia, sistem keuangan, penjualan, produksi dan seterusnya. Penerapan ERP di suatu organisasi atau perusahaan akan berpengaruh terhadap 
perubahan strategi manajemen suatu organisasi. Beberapa hal yang perlu diperhatikan dalam menerapkan sistem ERP pada organisasi atau perusahaan adalah perlunya suatu strategi perubahan terhadap manajemen organisasi serta dibutuhkan peningkatan dalam teknologi informasi yang berkelanjutan guna mendukung seluruh kegiatan operasional organisasi.

Sistem ERP sebagai information backbone bagi suatu perusahaan mampu mencover seluruh bagian dan rantai nilai dalam perusahaan. Untuk itulah strategi bisnis perusahaan untuk jangka panjang perlu diperhatikan dalam penentuan kriteria pemilihan sistem ERP. Proses pemilihan sistem ERP ini merupakan semi structured decision problem 'keputusan semi terstruktur' karena hanya sebagian yang dapat ditangani dengan prosedure baku seperti standar perhitungan investasi dan di sisi lain pengambil keputusan perlu untuk mengevaluasi secara detil semua aspek bisnis yang terkait. Dalam penelitian ini diasumsikan pengambil keputusan sudah melalui proses pemilihan modul sistem dan mengeliminasi modul-modul yang tidak sesuai dengan kebutuhan perusahaan.

\section{Model pengambilan keputusan dengan Analytical Hierarchy Process (AHP)}

Salah satu model yang dapat digunakan sebagai proses pengambilan keputusan adalah dengan dengan menggunakan Proses Hierarki Analitik atau yang dikenal dengan Analytical Hierarchy Process (AHP). Proses Hieraki Analitik (AHP) dikembangkan oleh Dr. Thomas L. Saaty dari Wharton School of Business pada tahun 1970-an untuk mengorganisasikan informasi dan judgement dalam memilih alternatif yang paling disukai (Santy,1983 dalam Marimin, 2005). Dengan menggunakan AHP, suatu persoalan dapat dipecahkan dalam suatu kerangka berpikir yang terorganisir sehingga memungkinkan untuk dapat diekspresikan dalam mengambil keputusan yang efektif atas persoalan tersebut. Persoalan yang kompleks dapat disederhanakan dan dipercepat proses pengambilan keputusannya.

Prinsip kerja AHP adalah menyederhanakan suatu persoalan kompleks yang tidak terstruktur, strategis dan dinamik menjadi bagian-bagiannya serta menata dalam suatu hierarki. Kemudian tingkat kepentingan setiap variabel diberi nilai numerik secara subyektif tentang arti penting variabel tersebut secara relatif dibandingan dengan variabel yang lain. Dari berbagai pertimbangan tersebut kemudian dilakukan sintesis untuk menetapkan variabel yang memiliki prioritas tertinggi dan berperan untuk mempengaruhi hasil pada sistem tersebut. Secara grafis, persoalan keputusan AHP dapat dikonstruksikan sebagai diagram bertingkat, yang dimulai dengan goal 'sasaran', lalu kriteria level pertama, sub kriteria dan akhirnya alternatif. AHP memungkinkan pengguna untuk memberikan nilai bobot relative dari suatu kriteria majemuk (atau alternatif majemuk terhadap suatu kriteria) secara intuitif, yaitu dengan melakukan perbandingan berpasangan (pairwase comparions). Dr. Thomas L. Saaty, pembuat AHP, kemudian menentukan cara yang konsisten untuk mengubah perbandingan pairwase 'berpasangan', menjadi suatu himpunan bilangan yang merepresentasikan prioritas relative dari setiap kriteria dan alternatif.

AHP memiliki banyak keunggulan dalam menjelaskan proses pengambilan keputusan karena dapat digambarkan secara grafis, sehingga dapat dipahami oleh semua pihak yang terlibat dalam pengambilan keputusan. Dengan AHP, proses pengambilan keputusan yang kompleks dapat diuraikan menjadi keputusan-keputusan lebih kecil yang dapat ditangani dengan lebih mudah. Selain itu, pendekatan dengan proses AHP juga dapat menguji konsistensi penilaian, bila terjadi penyimpangan yang terlalu jauh dari nilai konsistensi sempurna maka hal ini menunjukkan bahwa penilaian perlu diperbaiki atau hierarki harus distruktur ulang.

\section{Tinjauan Obyek Penelitian}

PT Ciliandra Perkasa didirikan di Jakarta pada tanggal 31 Juli 1992. Perusahaan ini adalah salah satu produsen swasta minyak sawit terbesar di Indonesia. Saat ini PT Ciliandra Perkasa telah memiliki 13 lahan perkebunan siap produksi dan 6 lahan perkebunan kelapa sawit yang berlokasi di 
Pulau Sumatra, provinsi Riau, Indonesia. Pada Desember 2006, total area perkebunan PT Ciliandra Perkasa terhitung sekitar 78,704 hektar dengan sekitar 55,944 hektar atau 71\% telah dijadikan lahan siap produksi. Pada tahun 2006, area lahan PT Ciliandra Perkasa memproduksi kombinasi dari total 1,120,765 ton buah segar, 227,286 ton minyak sawit (Crude Palm Oil) dan 47,759 ton kelapa sawit. PT Ciliandra Perkasa memiliki 37,689 hektar lahan yang belum digunakan dan berniat untuk menggunakan lahan tersebut terutama untuk perkebunan minyak sawit tambahan dan menghubungkan infrastruktur seperti pengembangan pohon untuk perkebunan, bangunan dan jalan.

PT Ciliandra Perkasa telah mencapai level tinggi dalam kompetisi bisnis yang telah ada saat ini dan sekarang hendak menggabungkan diri kepada bisnis hilir untuk menambah nilai produk. Sebagai contoh, PT Ciliandra Perkasa telah berinvestasi pada industri biodiesel. PT Ciliandra Perkasa telah menginvestasikan lahan sebanyak lima hektar di Kawasan Industri Dumai untuk 250,000 ton per annum tumbuhan biodiesel dan rekonstruksi saat ini sedang berlangsung. PT Ciliandra Perkasa memperkirakan bahwa produksi tanaman biodiesel tersebut dapat dipasarkan pada kuartal kedua di tahun 2008. PT Ciliandra Perkasa berharap bahwa permintaan pasar atas tanaman biodiesel dapat dipenuhi oleh produksi minyak kelapa sawit (Crude Palm Oil). PT. Ciliandra berharap atas pengembangan usaha ini dari waktu ke waktu semakin meningkat.

Seiring dengan berkembangnya perusahaan maka bisnis proses perusahaan pun berkembang semakin kompleks. Untuk itulah perusahaan mengambil langkah strategis dengan mengimplementasikan sistem ERP (Enterprise Resource Planning) untuk mengintegrasikan beberapa sub bisnis proses menjadi satu kesatuan. Beberapa sub bisnis proses tersebut antara lain: Sales, Purchasing, Inventory, Accounting (General Ledger, Fixed Asset) dan Finance (Account Payable, Account Receivable \& Cash Management). Pengguna sistem ERP tersebar di beberapa departemen, antara lain: department Sales, departemen Purchasing, departemen Accounting, departemen Finance dan departemen Logistik.

\section{Kerangka Konsep}

Dalam melakukan Pemilihan Perangkat Lunak sistem Enterprise Resouce Planning (ERP) di PT Ciliandra Perkasa, digunakan kriteria dan sub kriteria yang telah digunakan oleh Oyku Alanbay (2005) (Gambar 1). Kriteria dan sub kriteria tersebut terbagi menjadi tiga bagian besar yaitu: (1) kriteria technology-related, yaitu kriteria dan sub kriteria yang terkait dengan aspek teknologi; (2) kriteria use- related, yaitu kriteria dan sub kriteria yang terkait dengan kebutuhan pengguna atau end user; (3) kriteria vendor-related, yaitu kriteria dan sub kriteria yang digunakan oleh vendor yang akan melakukan proses implementasi.

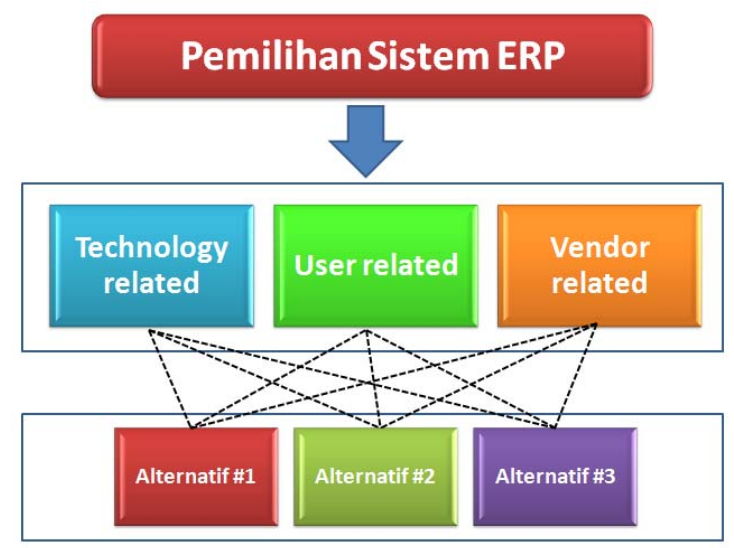

Gambar 1. Kriteria AHP Oyku Alanbay dengan tiga alternatif. 
Dengan dilakukannya penelitian yang berjudul "Analisis Pemilihan Perangkat Lunak Sistem Enterprise Resource Planning (ERP) dengan menggunakan Analytical Hierarchy Process (AHP), Studi Kasus: PT Ciliandra Perkasa” maka diambil hipotesis direksional sebagai berikut: (1) diduga kriteria technology related adalah kriteria yang paling penting dalam proses pemilihan perangkat lunak sistem ERP; (2) diduga Microsoft Dynamics AX merupakan prioritas alternatif yang utama pada proses pemilihan perangkat lunak sistem ERP.

\section{METODE}

Penelitian dilakukan dengan terlebih dahulu mempelajari teori-teori dan materi penelitian terdahulu (riset pustaka), dilanjutkan dengan melakukan survey (survey research) yaitu pembagian kuesioner untuk mengumpulkan data sampel pada suatu waktu tertentu (cross sectional survey) dari beberapa kelompok calon pengguna sistem ERP (Enterprise Resource Planning). Jenis penelitian ini adalah eksploratif yaitu penggalian fakta terhadap pemilihan perangkat lunak sistem ERP dengan studi kasus pada perusahaan perkebunan kelapa sawit, PT Ciliandra Perkasa.

\section{Pemilihan Sampel}

Dalam penelitian ini, data dan informasi dikumpulkan dari para responden dengan teknik wawancara dan pengamatan yang dilakukan pada para responden yaitu: akademisi, praktisi, para manajer (top management dan middle management) dan para pengguna sistem ERP. Diharapkan setelah melakukan ini, top management dan middle management akan mendapatkan keuntungan berupa alternatif pilihan untuk menentukan sistem ERP yang tepat dalam memenuhi dan mendukung kegiatan operasional perusahaan berdasarkan peringkat pembobotan.

\section{Pengumpulan Data}

Proses pengumpulan data dimulai dengan mencari data primer dengan melakukan survey sesuai dengan kebutuhan dan kondisi yang ada. Pada saat yang bersamaan, peneliti juga mencari data sekunder guna memperkaya pengetahuan dan literatur. Setelah data yang diperoleh memadai maka peneliti melakukan analisis kebutuhan dan membuat model dalam bentuk kuesioner. Selanjutnya kuesioner tersebut diberikan kepada 15 orang responden yang bertindak sebagai responden, yaitu: Top Management, Middle Management (para manajer atau kepala bagian) dan para pengguna di PT Ciliandra Perkasa.

\section{Instrumentasi}

Instrumentasi utama yang digunakan dalam penelitian ini adalah kuesioner. Detil kuesioner untuk pemilihan perangkat lunak sistem ERP dapat dilihat pada bagian Lampiran.

\section{Teknik Analisis Data}

Kuesioner pemilihan perangkat lunak sistem ERP akan memakai pendekatan proses hirarki dengan menggunakan aplikasi AHP yaitu Expert Choice 2000. Pada intinya aplikasi Expert Choice ini dapat dibagi menjadi enam langkah utama dalam melakukan proses analisis yaitu: (1) menyusun diagram hirarki AHP; (2) memasukkan data matriks pairwase comparison per level per responden pada aplikasi Expert Choice 2000; (3) memasukkan data pairwase comparison per sub-kriteria per alternatif per responden; (4) melakukan perhitungan dengan Expert Choice 2000 untuk menghitung hasil akhir seluruh responden; (5) melakukan pengecekan terhadap inconsistency gabungan melalui 
Expert Choice dan hitung dengan Random Index Oarkridge Laboratory; (6) melakukan kalkulasi nilai yang diterima, yaitu Consistency Ratio dengan nilai lebih kecil dan atau sama dengan 0,1.

\section{HASIL DAN PEMBAHASAN}

\section{Pengelompokan Data}

Responden dalam penelitian ini sejumlah 15 oramg yang terbagi dalam tiga kelompok, yaitu lima orang responden dari kelompok Low Management, tujuh orang responden dari kelompok Middle Management dan tiga orang responden dari kelompok Top Management. Seluruh responden berada di Kantor Pusat PT Ciliandra Perkasa yang akan menjadi bagian dari pengguna dari implementasi perangkat lunak sistem ERP di perusahaan ini.

\section{Pengolahan Data Responden}

Dalam pemilihan perangkat lunak sistem ERP sesuai dengan kriteria dari Oylu Alanbay terdapat tiga kriteria yaitu technology-related, user-related dan vendor-related. Pada studi kasus pemilihan perangkat lunak sistem ERP untuk PT Ciliandra Perkasa didapati hasil sebagai berikut (Gambar 2). Hasil analisis pendapat gabungan responden menunjukkan bahwa kriteria technology related (nilai bobot 0.400 atau sebanding dengan $40 \%$ dari total kriteria) merupakan kriteria yang paling penting menurut para responden dalam pemilihan perangkat lunak sistem ERP di PT Ciliandra Perkasa. Kriteria vendor related (nilai bobot 0.343 atau sebanding dengan 34,3\% dari total kriteria) menjadi pertimbangan kedua dalam memilih perangkat lunak sistem ERP. Sedangkan kriteria user related menjadi kriteria terakhir (nilai bobot 0.257 atau sebanding dengan 25,7\% dari total kriteria) yang dipertimbangkan dalam pemilihan perangkat lunak sistem ERP. Setelah melalui proses pengisian kuesioner oleh beberapa responden dan melalui perhitungan penggabungan data responden diperoleh nilai bobot alternative sebagai berikut (Gambar 3):

Berdasarkan hasil pengolahan data gabungan responden diperoleh bahwa prioritas utama atau tertinggi dari perangkat lunak sistem ERP yang dipilih adalah menggunakan perangkat lunak Microsoft Dynamics AX (bobot 0.480 atau setara 48\%). Prioritas kedua perangkat lunak sistem ERP yang dipilih adalah menggunakan perangkat lunak SAP ERP (bobot 0.266 atau setara 26,6\%). Sedangkan perangkat lunak alternatif terakhir adalah perangkat lunak Oracle e-Business Suite (bobot 0.254 atau setara $25,4 \%$ ). Semua kelompok responden juga mempunyai pendapat yang sama terhadap alternatif pemilihan perangkat lunak. Kelompok responden low level, middle level dan top level management sepakat untuk memilih perangkat lunak Microsoft Dynamics $A X$ sebagai pilihan utama.

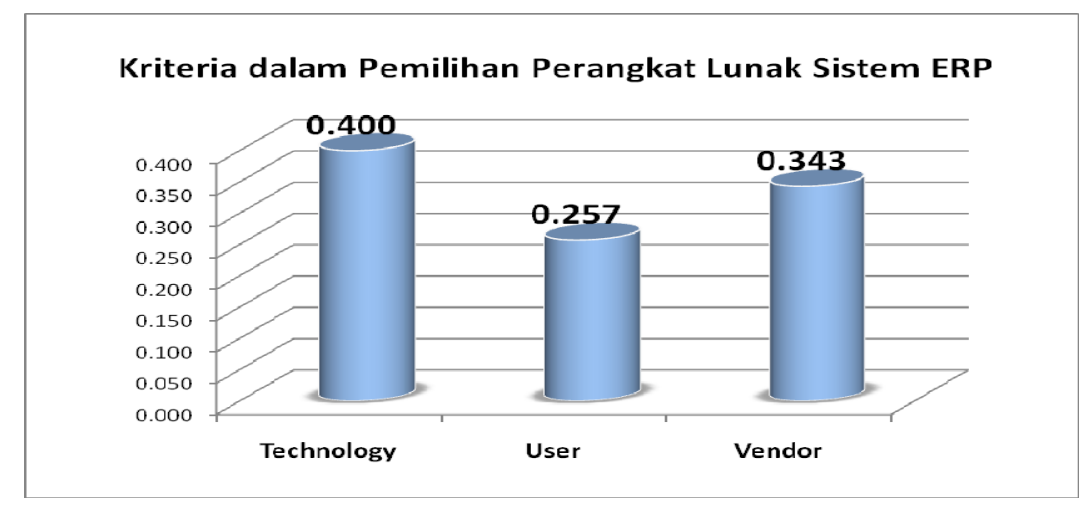

Gambar 2. Prioritas kriteria dalam pemilihan perangkat lunak sistem ERP. 


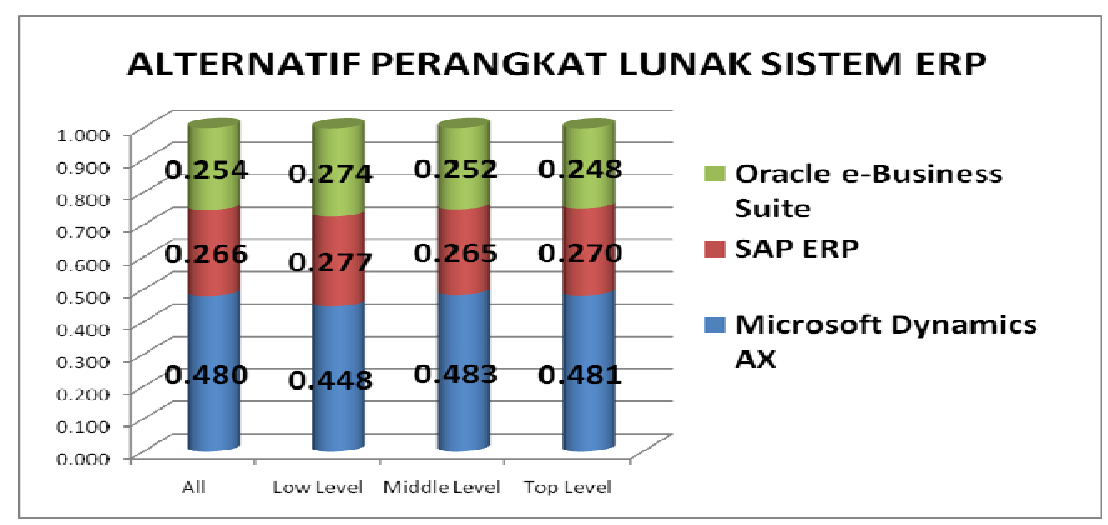

Gambar 3. Alternatif perangkat lunak sistem ERP yang dipilih.

\section{Incosistency Ratio}

Incosistency Ratio atau rasio inkonsistensi data responden ahli merupakan parameter yang digunakan untuk memeriksa apakah perbandingan berpasangan telah dilakukan dengan konsisten atau tidak. Rasio inkonsistensi data (Gambar 4) dikatakan baik jika nilai CR-nya $<=0,1$.

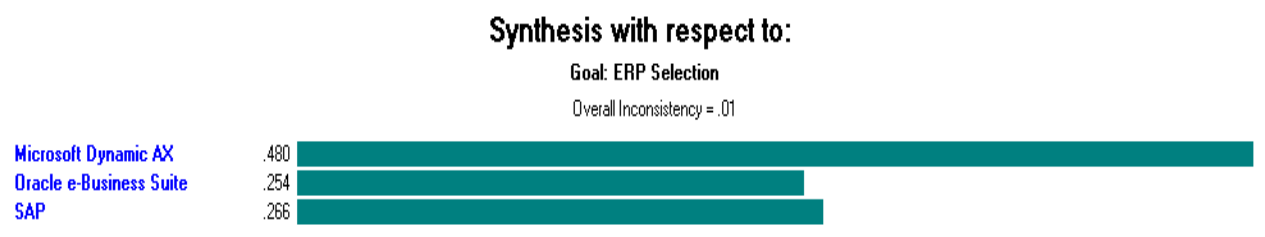

Gambar 4. Rasio inconsistensi keseluruhan.

Dari gambar di atas seluruh data perbandingan berpasangan yang diberikan responden memiliki rasio inkonsistensi di bawah 0,1 atau $10 \%$ sebagai batas maksimum nilai rasio inkonistensi. Dari pengolahan data responden dengan menggunakan Expert Choice 2000 diperoleh Overall Inconsistency-nya adalah 0,01. Hal ini berarti responden secara konsisten dan memahami dengan baik dalam memberikan pendapatnya.

\section{Implikasi Penelitian}

\section{Aspek Manajerial}

Hasil penelitian ini menyatakan bahwa perangkat lunak Microsoft Dynamics AX adalah perangkat lunak yang paling cocok untuk diimplementasikan di PT Ciliandra Perkasa. Setelah itu top management dapat mengeluarkan surat keputusan mengenai rencana implementasi perangkat lunak sistem ERP ini sekaligus memberikan sosialisasi atas keputusan ini kepada seluruh karyawan perusahaan agar mereka mendukung proyek implementasi ini.

Seperti diketahui bahwa proyek implementasi sistem ERP merupakan proyek yang krusial sehingga manajemen PT Ciliandra Perkasa harus mempersiapkan rencana implementasi ini dengan sebaik-baiknya, mulai dari sumber daya manusia yang dilibatkan sebagai tim proyek implementasi dan penyusunan jadwal proyek bersama dengan vendor atau mitra implementasi yang ditunjuk. Selain itu perlu dipersiapkan pula membentuk team khusus yang mengatur masalah perubahan manajemen untuk mendukung keberhasilan implementasi sistem ERP ini. 


\section{Aspek Sistem}

Dari penelitian ini dapat diperoleh gambaran teknis terkait dengan rencana implementasi perangkat lunak sistem ERP di PT Ciliandra Perkasa. Untuk itu, tim yang dilibatkan dalam proses pemilihan perangkat lunak sistem ERP ini perlu segera mengkaji ulang kebutuhan infrastruktur yang diperlukan, mulai dari kebutuhan hardware seperti: application server, database server, jaringan local area network (LAN), jaringan wide area network (WAN), perangkat-perangkat lunak yang terkait dengan perangkat lunak sistem ERP. Hal tersebut perlu dilakukan untuk mengetahui tingkat compability terhadap perangkat lunak Microsoft Dynamics $A X$. Bila ditemukan adanya perangkat lunak yang tidak mendukung, perlu ditemukan solusinya: apakah perlu melakukan upgrade atau memutuskan untuk membeli perangkat lunak yang baru.

Selain itu, tim proyek implementasi sistem ERP ini perlu menyiapkan dokumentasi teknis terkait dengan existing system atau business process yang berjalan saat ini. Hal ini diperlukan untuk memperlancar proses implementasi sistem ERP ini, termasuk rencana go live atau change over terhadap sistem yang lama.

\section{Aspek Penelitian Selanjutnya}

Penelitian ini dapat diterapkan atau digunakan serta dikembangkan pada proses pemilihan perangkat lunak secara umum atau pun juga pemilihan perangkat lunak sistem ERP yang akan diterapkan pada berbagai jenis industri.

Penelitian ini juga dapat diperluas dengan menambahkan kriteria-kriteria dan sub kriteria-sub kriteria yang menentukan di masa mendatang. Penelitian ini dapat dikembangkan pula menjadi dua tahap, yaitu: (1) tahap mengenai proses pemilihan perangkat lunak sistem ERP; (2) tahap mengenai proses pemilihan vendor atau mitra implementasi sistem ERP karena biasanya suatu perangkat lunak sistem ERP yang dibangun oleh suatu vendor atau principal dapat diimplementasikan oleh beberapa mitra lokal.

Selain hal tersebut di atas, penelitian ini dapat dilakukan secara berulang untuk memastikan apakah seiring dengan berjalannya waktu dan kemajuan teknologi, metode dan validasi dari kriteria dan sub kriteria serta alternatif pilihan dari penelitian ini masih berlaku atau tidak. Berkaitan dengan implementasi perangkat lunak sistem ERP ini dapat juga dilakukan penelitian mengenai dampak dari implementasi sistem ERP terhadap kinerja perusahaan yang telah mengimplementasikan sistem ERP.

\section{PENUTUP}

\section{Kesimpulan}

Berdasarkan hasil penelitian dan pengolahan data responden menggunakan aplikasi Expert Choice 2000 diperoleh beberapa kesimpulan.

Pertama, terdapat tiga kriteria yang menjadi pertimbangan dalam pemilihan perangkat lunak sistem ERP. Kriteria tersebut adalah kriteria technology-related, user-related dan vendor-related. Dari ketiga kriteria tersebut, kriteria technology related merupakan prioritas utama dalam pemilihan perangkat lunak sistem ERP. Sedangkan prioritas kedua adalah kriteria vendor related karena kelompok responden berpendapat bahwa kemampuan dan kredibilitas vendor dalam proses implementasi memberikan peranan yang cukup penting juga. Hal inilah yang disadari sepenuhnya oleh kelompok responden top level dan middle level management. Sedangkan low level management lebih 
cenderung memilih user related sebagai prioritas kedua karena hal tersebut terkait dengan aktivitas kerja mereka sehari-hari dalam operasional perusahaan sebagai pengguna sistem ERP atau end users. Dalam kriteria technology related, sub kriteria yang menjadi prioritas adalah sub kriteria flexibility. Sub kriteria flexibility ini menjadi prioritas utama karena didasari bahwa perangkat lunak sistem ERP diharapkan dapat memberikan kemudahan dan kemampuan untuk mendukung kebutuhan bisnis untuk jangka waktu yang panjang. Karena kebutuhan bisnis dapat berubah di waktu yang akan datang maka sistem ERP harus dapat menambah modul baru (extra modules). Untuk itulah sistem ERP harus fleksibel dalam menyesuaikan dengan budaya organisasi dan strategi bisnis. Sedangkan kelompok responden top level management lebih memilih sub kriteria real time changes sebagai sub kriteria yang utama karena didasari dengan pertimbangan bahwa sistem ERP adalah perangkat lunak yang mendukung proses transaksi dari seluruh departemen maka transaksi-transaksi perlu diproses secara real time agar dapat menyajikan berbagai informasi untuk proses pengambilan keputusan oleh top level management.

Kedua, mengenai perangkat lunak sistem ERP yang dipilih untuk diimplementasikan dari tiga alternatif - Microsoft Dynamics AX, SAP ERP dan Oracle e-Business Suite - maka berdasarkan pengolahan data dari para responden didapatkan bahwa Microsoft Dynamics $A X$ adalah perangkat lunak sistem ERP pilihan utama. Hipotesa yang dirumuskan bahwa perangkat lunak Microsoft Dynamics $A X$ adalah perangkat lunak yang cocok untuk diimplementasikan di PT Ciliandra Perkasa, terbukti dari hasil pengolahan data didapati perangkat lunak Microsoft Dynamics AX menjadi pilihan pertama dari para responden (bobot 0.480 atau setara 48\%).

Ketiga, untuk kriteria yang menjadi prioritas utama maka didapati kriteria technology related merupakan prioritas utama dalam pemilihan perangkat lunak sistem ERP. Hipotesa yang dirumuskan bahwa kriteria technology related adalah kriteria utama, terbukti dari hasil pengolahan data didapati kriteria technology related menjadi pilihan pertama dari para responden (bobot 0.400 atau setara $40 \%)$.

\section{Saran}

Kiranya apa yang telah ditulis dalam penelitian ini dapat bermanfaat dan dapat dijadikan landasan dalam menentukan pilihan ketika suatu perusahaan atau organisasi akan mengimplementasikan perangkat lunak sistem ERP. Beberapa saran untuk pengembangan dari penelitian ini adalah: (1) Hasil penelitian ini dapat diterapkan atau digunakan serta dikembangkan pada pada proses pemilihan perangkat lunak secara umum atau pun juga pemilihan perangkat lunak sistem ERP yang akan diterapkan pada berbagai jenis industri; (2) Model AHP Oyku Alanbay ini bisa digunakan untuk proses pemilihan perangkat lunak atau kebutuhan perangkat keras lainnya yang digunakan di PT Ciliandra Perkasa. Model AHP Oyku Alanbay ini bisa dikembangkan dengan menambahkan beberapa kriteria dan sub kriteria yang diperlukan untuk proses pemilihan perangkat lunak atau kebutuhan perangkat keras lainnya; (3) Penelitian ini dapat diperluas dengan menambahkan kriteria-kriteria dan sub kriteria-sub kriteria yang menentukan di masa mendatang. Penelitian ini dapat dikembangkan pula menjadi dua tahap, yaitu tahap pertama mengenai proses pemilihan perangkat lunak sistem ERP dan tahap kedua mengenai proses pemilihan vendor atau mitra implementasi sistem ERP karena biasanya suatu perangkat lunak sistem ERP yang dibangun oleh suatu vendor atau principal dapat diimplementasikan oleh beberapa mitra lokal; (4) Agar pelaksanaan implementasi sistem ERP di PT Ciliandra Perkasa dapat berhasil dengan baik perlu memperhatikan beberapa faktor penting lainnya antara lain: effective project managemet, user involvement, business process reengineering dan transfer knowledge.

Sebagai alat bantu dalam proses pengambilan keputusan terkait kebutuhan pemilihan perangkat lunak Sistem ERP, penelitian ini masihlah belum sempurna sehingga memerlukan masukan, saran dan kritik yang membangun supaya dapat memperbaiki dan mengembangkan penelitian ini. 


\section{DAFTAR PUSTAKA}

Alanbay, Oyku. (2005). ERP Selection using Expert Choice Software. Istanbul: Istanbul Bilgi University.

Jogiyanto, H. M. (2005). Analisis dan Desain Sistem Informasi: Pendekatan Terstruktur Teori Dan Praktek Aplikasi Bisnis. Yogyakarta: Andi Offset.

Marimin. (2005). Teknik dan Aplikasi Pengambilan Keputusan Kriteria Majemuk. Jakarta: Gramedia

Saaty, T. L. (1994). Fundamentals of Decision Making and Priority Theory with the Analytic Hierarchy Process. Pittsburg PA: RWS Publications.

Turban, Efraim. (2006). Information Technology for Management. New Jersey: John Wiley \& Sons. 